Noel J. Coulson/Abdelwadoud Yehia

\title{
Studien zum Islamischen Recht
}

Herausgegeben von Fritz Schwind. Verlag der Osterreichischen Akademie der Wissenschaften, Wien 1983, $37 \mathrm{~S}$.

Die kleine Schrift enthält auf 37 Seiten drei Artikel, die anläßlich einer Tagung der österreichischen Gesellschaft für Rechtsvergleichung und des Instituts für Rechtsvergleichung der Universität Wien im Jahre 1980/81 als Vorträge gehalten wurden. Die Autoren Coulson - an der School of Oriental and African Studies in London tätig - und Yehia - von der Universität Kairo - vermitteln grundlegende Kenntnisse über das islamische Rechtswesen, einige Aspekte des Familienrechts - namentlich des Kindschafts- und des Scheidungsrechts im allgemeinen - und das neuere Ehescheidungsrecht in Ägypten. Sie geben auch dem inteŕessierten Leser, der über keinerlei Vorkenntnisse verfügt, eine knappe und fundierte Einführung in die islamische Gedankenwelt, die eine säuberliche Trennung von Recht und Religion nicht kennt, sie legen Grundzüge der vier islamischen Rechtsquellen dar und weisen auf Veränderungen der Rechtsanschauungen in der modernen Zeit hin. Daß die Schrift kein Detailwissen vermitteln kann und will, versteht sich aus ihrer Konzeption, auf die der Herausgeber eingangs hinweist, nämlich "die interessierte österreichische Ơfentlichkeit mit dem aktuellen Stand und den wichtigsten Problemen des Islamischen Rechts vertraut zu machen ".

Dagmar Hohberger

\section{Naomi Chazani}

An Anatomy of Ghanaian Politics. Managing Political Recession 1969-1982

Westview Special Studies on Africa; Westview Press Inc., Boulder Colorado, 1983, 429 p.

Newspaper headlines especially in Africa South of the Sahara have been indicative of the events taking place in Ghana, and in fact this particular country championing political independence for the many black African states in 1957 has come to be a subject of many studies of which the anatomy provided by Naomi Chazani comprises the latest and actually one of the most informative about Ghana's problem. Naomi Chazani sets out to examine Ghana between the rise and the fall of Busia's civilian government brought about by the soldiers in 1972 to the usurpation of power from the civilian by the Rawling revolutionaries in 1982. In her preface Dr. Chazani strikes the tunes of reality in describing Ghana in that being the first African country to gain independence, the people of Ghana have known hope and despair, abundance and scarcity, international recognition and external neglect, innovation and continuity, progress and underdevelopment. 
Today Ghana has plunged into a recession which has tended to create little hope and diminishing expectations.

Chazani's work is a comprehensive study of Ghana, done in four parts comprising together twelve chapters. Very important for the reader who knows little about Ghana's political climates is the first chapter, which comprises an overview of Ghana's political patterns between the researched period. It is in fact an eye-opening chapter and prepares the reader to what follows.

Dr. Chazani goes further, in other chapters, to examining in details the components of politics in Ghana, by moving into an analysis of the anatomy of political structures which indicate a complex network of social forces. She establishes the fact that these social foundations are the sources of political action in Ghana, and she analyzes the relationship between the State and political action in Ghana, political processes and institutions, the changing political economy and gives an examination of the seven different regimes which dominated Ghanaian politics in the study period.

The author employs her political science and analytical methods by going deeply into the structure of Ghanaian politics and by examining, with convincing analyses, the sources leading to the decline of state power and authority and the adjustments of the resulting political recession. Her research is based in Ghana, and she refers directly to events within Ghana as the ground work for the political recession. She does not retire out to the imperialist world to look for external sources of the observed trends. One gets the message that the managers for the political recession and those ones who attempt to avert it are in Ghana.

Despite the comprehensive analysis of Ghanaian politics, Dr. Chazani might not be very much of a help to the radical school of thought which employs strictly marxist class analysis for problems typical of Ghana and other "Third World Countries". Much as this approach is missing the analysis it bears scientific constructions which makes the book rank as one of the most realistic attempts to examine without prejudice the state of politics in African countries.

Costa R. Mahalu

\section{Kurt Eitner}

\section{Nigeria. Auswahlbibliographie}

Band I: Landeskunde, Politik, Recht (908 Titel; XIV, 131 S.); Band II: Wirtschaft, Gesellschaft (985 Titel; XIV, 143 S.); Reihe A - 20/I+II; Dokumentations-Leitstelle Afrika, Hamburg, 1983; je Band DM 22,-, beide Bände zusammen DM 40,-

Die vorliegende zweibändige Bibliographie verdient Beachtung. Mit ihr wird erstmals die für das heutige Nigeria maßgebliche Entwicklung der siebziger Jahre bis 1982 in knapp 1900 Titeln von Veröffentlichungen, die zwischen 1975 und 1982 erschienen sind, 